\title{
NOTES AND COMMUNICATION
}

\section{The Srebrenica Genocide: Seventeen Years After}

\author{
Senad Mrahorović*
}

In the beginning of 2012, the people of Bosnia and Herzegovina have once again witnessed disturbing events in the Bosnian entity known as Republika Srpska. Several distinguished personalities were awarded the highest decoration, including Boris Tadić, the current president of the Republic of Serbia. With this award, President Tadić has been added to the list of people who previously have received the same decoration, such as Radovan Karadžić, Ratko Mladić, Slobodan Milošević and others who were indicted by the International Criminal Tribunal for the Former Yugoslavia (ICTY) for charges of genocide and other war crimes committed during the war in Bosnia and Herzegovina in the early 1990s. While the trial of Milošević lasted for almost two years, it did not end, however, owing to his sudden death. The other two figures namely, Karadžić and Mladić, are currently being tried in The Hague by the ICTY.

To remind the readers, let me say that for the period of four years, from 1991 to 1995 , the Bosnian people were exposed to the highest degree of aggression on their country since the Second World War. During this period, numerous crimes were committed by Bosnian Serbs who were throughout the war supported by the then Federation of Yugoslavia (of which Serbia was a part at that time), mainly against Bosniaks (Bosnian Muslims). The crimes in question refer to ethnic cleansing and constituted, according to the UN General Assembly, genocide. ${ }^{1}$ This crime is especially applied to the town of Srebrenica, which at that time was proclaimed a 'safe zone' by the UN. However, in the summer of 1995, Serbian forces from both Bosnia and Serbia attacked unarmed people of Srebrenica who were supposed to be protected by the UN. The consequence of that attack was devastating, to say the least. More than eight thousand Muslims, mostly men and boys, were killed. Thousands of others, including women and children, were displaced, tortured, and raped, while major portions of Muslim property, infrastructure, religious monuments and cemeteries were destroyed. Based on these and other consequences, the ICTY declared in 2001 that the slaughter and atrocities committed against Muslims in Bosnia and Herzegovina had reached the degree of genocide. ${ }^{2}$

* Senad Mrahorović is a PhD candidate at the International Institute of Islamic Thought and Civilization (ISTAC), International Islamic University Malaysia (IIUM), Kuala Lumpur. 
Having said this, the policy of Bosnian Serbs as well as the Republic of Serbia concerning these bloody events in Bosnia in which they took a decisive and negative role alongside the international community that failed to stop them, evidently seems to be the same today. Not only did the Serbs not acknowledge the level of violence caused by them toward the main constituent part of the Bosnian nation - the Muslims - they seem to be proud of their role and actions, as the recent events show. The celebration of the national day of the Republika Srpska (a state born out of genocide and as such only recognised by the Serbs themselves), appreciation through awards given mostly to those who are directly responsible for the genocide, and public and official tribute to the range of heroism conferred on those who are legitimately labeled by the UN as murderers and slaughterers are just some examples to demonstrate the policy which is being practiced by the government of the Republika Srpska with the full support of the Republic of Serbia. These and similar attitudes which day by day are on the rise completely overshadow an apology from the Serbian Government to Bosnia and Herzegovina, given only after it was finally proved by the International Court of Justice that Serbia was guilty of not preventing genocide in Bosnia and Herzegovina. ${ }^{3}$

While thousands of victims of the Srebrenica genocide are still looking to recover the bodies of their loved ones killed during those bloody years of war and to bury them next to thousands of others in a memorial cemetery in Srebrenica, Serbian and Bosnian Serbian dignitaries are celebrating at the same time the anniversary of the Republika Srpska, an entity where the actual genocide took place.

To make matters worse, just three days after the controversial anniversary of the "dreamed republic" of the Bosnian Serbs, the British newspaper The Independent, published parts of a letter claimed to have been written sometime in 1993 by John Major, the former British Prime Minister. In it, he said that no Western action should be taken to stop the war in Bosnia, until "Bosnia-Herzegovina no longer exists as a viable state and its Muslim population is totally displaced from its land"! The explanation for such a stance is given further in the letter under the pretext that it is "in the best interests of a stable Europe in the future, whose value system is and must remain based on "Christian civilisation"'! ${ }^{4}$ Needless to say, the British Government has immediately acted on this matter, claiming the letter was a fake, and dismissing it completely.

\section{Conclusion and Recommendations}

Be that as it may, according to many analysts and experts such as Muhamed Filipović, a distinguished professor from Bosnia, Bosnia and Herzegovina is currently going through the worse times since the war. ${ }^{5}$ 
- Besides the current economic crisis affecting almost every part of the world, the Bosnian nation is also facing cruel socio-political battles which only aggravate the recovery of the country.

- Religious extremism in the form of Wahhabism as well as fanaticism shown by certain authorities of the Bosnian Orthodox Church is yet another problem. It disturbs centuries-long religious and cultural coexistence in the region.

- The current events relating to the Republika Srpska increase doubts about the prospects of a lasting peace and stability in Bosnia and Herzegovina.

- If the situation continues on its current course without international intervention, then there will be rising concern that Bosnia would once again be at the losing end of its difficult battle.

- It is therefore necessary to take appropriate measures in order to overcome distrust and mutual ethnic and religious prejudice in Bosnia and Herzegovina.

\section{Notes}

1. http://www.un.org/documents/ga/res/47/a47r121.htm (accessed on 2 February 2012).

2. http://www.worldlii.org/int/cases/ICTY/2001/8.html (accessed on 2 February 2012). In 2004, this decision was once again reaffirmed by then the Presiding Judge of ICTY, Mr Theodor Meron, who at the Potočari Memorial Cemetery (Srebrenica) has stated the following: "By seeking to eliminate a part of the Bosnian Muslims the Bosnian Serb forces committed genocide. They targeted for extinction the forty thousand Bosnian Muslims living in Srebrenica, a group which was emblematic of the Bosnian Muslims in general. They stripped all the male Muslim prisoners, military and civilian, elderly and young, of their personal belongings and identification, and deliberately and methodically killed them solely on the basis of their identity". For the full text see http://www.icty. $\mathrm{org} / \mathrm{sid} / 8409$ (accessed on 2 February 2012). Also International Court of Justice (ICJ) on 26 February 2007 concurred with ICTY's earlier findings that the Srebrenica massacre constituted genocide. For more on this see http://www.icj-cij.org/presscom/index.php?pr=1897\&pt=1\&p1=6\&p2=1 (accessed on 2 February 2012).

3. See http://news.bbc.co.uk/2/hi/8594625.stm and http://www.icj-cij.org/presscom/index. php?pr=1897\&pt=1\&p1=6\&p2=1 (both accessed on 2 February 2012).

4. http://www.independent.co.uk/news/world/europe/no-10-denounces-antimuslim-letter-hoaxhighlights-bosnian-muslims-fear-of-abandonment-by-the-west-1491727.html (accessed on 2 February 2012).

5. The full interview of Muhamed Filipovic was published at http://bosnjaci.net/prilog.php?pid=44678 (accessed on 2 February 2012). 